Acta Horticulturae et Regiotecturae 1

Nitra, Slovaca Universitas Agriculturae Nitriae, 2017, pp. 19-23

\title{
IMPLEMENTATION OF THE AHP METHOD FOR DETERMINING THE WEIGHTS OF FACTORS DECISIVE FOR THE LOCATION OF THE MUNICIPAL WASTE CONVERSION PLANT, ON THE EXAMPLE OF THE CITY OF KRAKOW
}

\author{
Monika SIEJKA*, Monika MIKA \\ University of Agriculture in Krakow, Poland
}

\begin{abstract}
The paper proposes a methodology for calculating the weights of factors determining the choice of location of municipal waste incineration plant (MWIP). Objective and accurate determination of the weights offers the optimal choice of location. To achieve the planned purpose, the method of the analytical hierarchical process was applied. The study included seven potential locations for the municipal waste incineration plant, located within the area of the city of Krakow. The objective of the analysis, which is the subject of this publication, is determination of weights of factors decisive for the choice of MWIP location. These weights were calculated using the method of the analytical hierarchical process. The choice of the method is dictated by the fact that in the studied case we deal with multivariate analysis, and its components are described both in quantitative and qualitative ways.
\end{abstract}

Keywords: AHP analysis, waste management

Waste management is a global problem and it becomes increasingly important due to the population growth, industrialization, as well as lifestyle changes. Currently, the majority of generated waste is neutralized in open dumps. Dumping of wastes causes many environmental problems. Construction of municipal waste incineration plants is the optimum solution. Poland is obliged to implement the principles of the EU Directive concerning wastes management and environmental protection. The adopted environmental policy indicates support for the implementation of cost-effective and environmentally sound technologies of recovery and disposal of wastes as one of the main directions of activities in the municipal sector. This also applies to technologies related to the recovery of the energy contained in wastes.

The National Waste Management Plan implies, inter alia, that in the nearest future, extension of the existing and construction of new lines for recovery and disposal of waste will be necessary. This applies both to thermal and biological methods. Construction of MWIP will help to reduce the number of open landfills in the country.

Selection of site for a municipal waste disposal plant is becoming a challenge in many countries around the world (Greco et al., 2001; Haining, 2003). That is why it is so important to develop methods to optimize the location of such a facility, taking into account not only technical factors. Optimization of location selection should take place in two basic stages. The first step is to find suitable areas that meet the technical conditions. Stage two is the choice of where the location of such a facility will have the least impact on the environment and will therefore provide the basis and arguments for environmental consultation (Yoxas et al., 2011; Zelenovic Vasiljevic et al., 2012).

The novelty of this paper is the use of the AHP method for determination of weights for factors decisive for the choice of MWIP location. MWIP site selection needs the use the multivariate analysis and its components are described both in quantitative and qualitative ways.

\section{Material and methods}

The implementation of the tasks arising from the EU Directive concerning waste management and environmental protection is related to the choice of locations for MWIP. The location of this type of investment requires consideration of factors of legal-social, technological, economic and ecological character. These factors are discussed in detail in Table 1.

The research was conducted using the analytic hierarchy proces (AHP). This method is one of the methods of solving multivariate tasks by creating a hierarchy structure in the form of a decision tree (Figure 1). The main advantage of the AHP is a complex multi-band and multi-criteria model presented in hierarchical terms (Saaty, 1977).

Considering the choice of MWIP location as a set of features $\left(w_{1}, w_{2}, \ldots, w_{n}\right)$, pairwise comparison matrices were constructed, in the form: 


$$
A=\left[\begin{array}{cccc}
\frac{w_{1}}{w_{1}} & \frac{w_{1}}{w_{2}} & \cdots & \frac{w_{1}}{w_{n}} \\
\frac{w_{2}}{w_{1}} & \frac{w_{2}}{w_{2}} & \cdots & \frac{w_{2}}{w_{n}} \\
\vdots & \vdots & \vdots & \vdots \\
\frac{w_{n}}{w_{1}} & \frac{w_{n}}{w_{2}} & \cdots & \frac{w_{n}}{w_{n}}
\end{array}\right] \cdot\left[\begin{array}{c}
w_{1} \\
w_{2} \\
\vdots \\
w_{n}
\end{array}\right]=n \cdot\left[\begin{array}{c}
w_{1} \\
w_{2} \\
\vdots \\
w_{n}
\end{array}\right]
$$

After transformation the following formula was obtained:

$$
\boldsymbol{A} \times \boldsymbol{w}=\boldsymbol{n} \times \boldsymbol{w} \quad \text { meaning } \quad|\boldsymbol{A}-\boldsymbol{n} \times \boldsymbol{I}| \times \boldsymbol{w}=0
$$

where:

$$
\begin{array}{ll}
\boldsymbol{A} & \text { - square matrix } \\
\boldsymbol{w} & - \text { vector of weights } \\
\boldsymbol{n} & - \text { matrix dimension } \\
\boldsymbol{I} & \text { - identity matrix }
\end{array}
$$

Matrix algebra shows that apart from the solution, wherein $\boldsymbol{w}=0$, the first factor, $|\boldsymbol{A}-\boldsymbol{n} \times \boldsymbol{I}|$ is equal to zero only when the dimension of the matrix $\boldsymbol{n}$ is equal to the matrix eigenvalue, and $\boldsymbol{w}$ is the eigenvector associated with the eigenvalue (Haining, 2003).

However, in practice, especially in the analyzed case, the factor $a_{i j}=w_{i} / w_{i}$, is associated with the evaluation, and in a situation where it is not based on accurate measurements, the factor $a_{i j}$ differs from the "ideal" value $w_{i} / w_{j}$ and therefore the equation (2) will be modified to the following form:

$$
\mathbf{A}^{\prime} \times \mathbf{w}^{\prime}=\lambda_{\max } \times \mathbf{w}^{\prime} \quad \text { or } \quad\left|\mathbf{A}^{\prime}-\lambda_{\text {max }}\right| \mid \times \mathbf{w}^{\prime}
$$

where:

$\lambda_{\max }-$ is the maximum real eigenvalue of the matrix $\mathbf{A}^{\prime}$

It is worth noting that the matrix $\mathbf{A}^{\mathbf{\prime}}$ has a specific structure:

- all elements

- elements on the diagonal $a_{i j}>0$

- elements on opposite sides of the diagonal

The matrix $\mathbf{A}^{\prime}$ presented above has always a real and positive eigenvalue $\lambda$, which has the following features (Haining, 2003):

1. It is a simple root of the characteristic equation of this matrix.

2. It is the largest one in terms of module eigenvalue of the matrix, and eigenvector $\mathbf{w}$ corresponding to this eigenvalue has always all components positive $\left(w_{i}>0\right)$.

In order to determine priorities (weights) after building the evaluations matrix, for each array the maximum eigenvalue $\lambda_{\max }$ and the eigenvector $\mathbf{w}$ associated with that value were determined.

In order to verify the correctness of the obtained results, two indicators were introduced (Greco, Matarazzo and Słowiński, 2001):

1. Consistency index $-\mathrm{Cl}$ :

$$
C l=\frac{\lambda_{\max }-n}{n-1} \leq 0.10
$$

where:

$\mathrm{n} \quad$ - dimension of the matrix

$\lambda_{\max }-$ maximum eigenvalue of the matrix

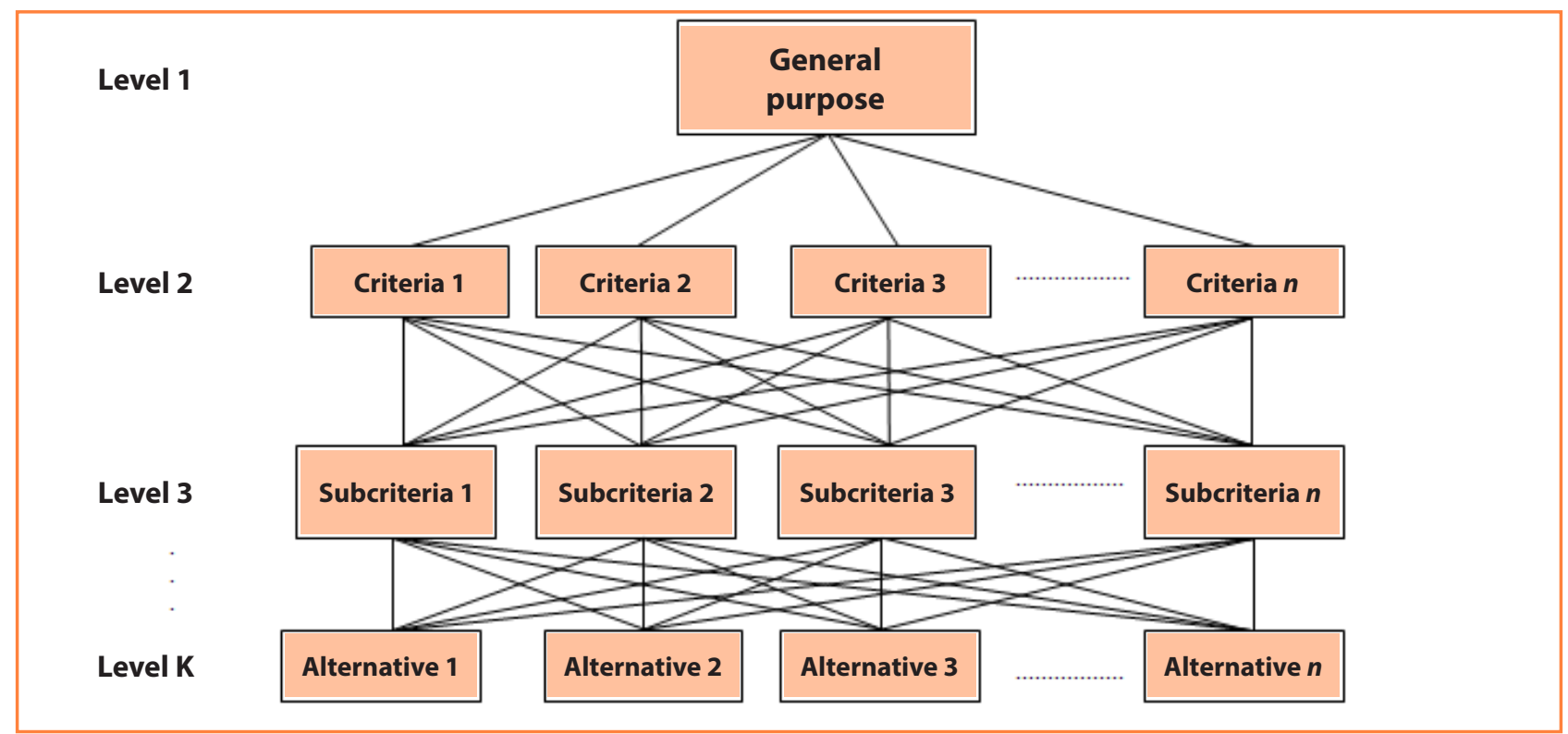

Figure 1 Example of the hierarchy decision tree

Table 1 Random index $R /$ value depending on the dimension $\boldsymbol{n}$ of the matrix

\begin{tabular}{|l||c|c|c|c|c|c|c|c|c|c|c|c|c|c|c|}
\hline $\mathbf{n}$ & 1 & 2 & 3 & 4 & 5 & 6 & 7 & 8 & 9 & 10 & 11 & 12 & 13 & 14 & 15 \\
\hline $\boldsymbol{R I}$ & 0 & 0 & 0.58 & 0.90 & 1.12 & 1.24 & 1.32 & 1.44 & 1.45 & 1.49 & 1.51 & 1.53 & 1.56 & 1.57 & 1.59 \\
\hline
\end{tabular}

Source: Saaty, 1980 
2. Consistency ratio $-C R$ :

$$
C R=\frac{C l}{R l} \leq 0.1
$$

where:

RI - (random index) depends on the size $n$ of the matrix (Table 1)

When the consistency ratio $C R>0.1$ or consistency index $\mathrm{Cl}>0.1$, evaluation of the relation of elements in the matrix must be repeated.

After determining all the partial priorities, the solution of the task is the vector:

$$
C[1, k]^{T}=\prod_{i=2}^{k} B_{i}=B_{k} \cdot B_{k-1} \ldots B_{2}
$$

where:

$C[1, k]$-vector of results of priorities (weights) assigned to elements of hierarchical level $k$, (i.e. alternatives of solutions) relative to the target, which is the first level

$B_{i} \quad$ - level $i$ matrix, whose columns are priorities vectors of $i$ level elements relative to the element of $i-1$ level

\section{Results and discussion}

The presented method was used for achieving the goal which was to determine the weights of the factors influencing the choice of MWIP location. After solving pairwise the 23 comparisons matrices ( 1 comparison matrix on the first level, 4 comparison matrices on the second level and 18 comparison matrices on the third level), the weights of features at various levels of the hierarchy were obtained. The results are summarized in Table 2.

In a further step of the analysis, the resulting weights were used in the evaluation of the investigated objects. The

\begin{tabular}{|c|c|c|c|c|c|}
\hline $\begin{array}{l}\text { Level I } \\
\text { Criteria }\end{array}$ & $\begin{array}{l}\text { Weight } \\
(\%)\end{array}$ & $\begin{array}{c}\text { Level II } \\
\text { Subcriteria } \\
\end{array}$ & $\begin{array}{l}\text { Weight } \\
(\%)\end{array}$ & $\begin{array}{c}\text { Level III } \\
\text { Components } \\
\end{array}$ & $\begin{array}{c}\text { Weight } \\
(\%)\end{array}$ \\
\hline \multirow{13}{*}{$\begin{array}{l}\text { Legal/ } \\
\text { Social }\end{array}$} & \multirow{13}{*}{35} & \multirow{3}{*}{$\begin{array}{l}\text { compliance with the spatial development } \\
\text { plan }\end{array}$} & 5 & full & 3.00 \\
\hline & & & & partial & 1.50 \\
\hline & & & & none & 0.50 \\
\hline & & \multirow{3}{*}{ the current usage } & 3 & residential areas & 1.50 \\
\hline & & & & agricultural areas & 0.75 \\
\hline & & & & forest areas & 0.75 \\
\hline & & \multirow{3}{*}{ legal status / ownership } & 7 & areas of legal status regulated - fully & 3.00 \\
\hline & & & & areas of legal status regulated - partly & 2.50 \\
\hline & & & & areas of unregulated legal status & 1.50 \\
\hline & & \multirow{3}{*}{ expected public acceptance } & 20 & favourable & 9.00 \\
\hline & & & & average & 6.00 \\
\hline & & & & adverse / none & 5.00 \\
\hline & & sum & 35 & & 35.00 \\
\hline \multirow{13}{*}{ Technical } & \multirow{13}{*}{20} & \multirow{3}{*}{ the size of the land } & 5 & favourable /optimal & 3.00 \\
\hline & & & & average & 1.50 \\
\hline & & & & adverse & 0.50 \\
\hline & & \multirow{3}{*}{ access to technical infrastructure } & 3 & favourable & 1.75 \\
\hline & & & & average & 0.75 \\
\hline & & & & adverse & 0.50 \\
\hline & & \multirow{3}{*}{ communication system } & 4 & favourable & 2.50 \\
\hline & & & & average & 1.05 \\
\hline & & & & adverse & 0.45 \\
\hline & & \multirow{3}{*}{$\begin{array}{l}\text { geological conditions / ground waters / } \\
\text { flood risk }\end{array}$} & 8 & favourable & 4.25 \\
\hline & & & & average & 2.80 \\
\hline & & & & adverse & 0.95 \\
\hline & & sum & 20 & & 20.00 \\
\hline
\end{tabular}

Table 2 The factors influencing the choice of MWIP location and their weights 


\section{Continue the table 2}

\begin{tabular}{|c|c|c|c|c|c|}
\hline $\begin{array}{l}\text { Level I } \\
\text { Criteria }\end{array}$ & $\begin{array}{l}\text { Weight } \\
(\%)\end{array}$ & $\begin{array}{c}\text { Level II } \\
\text { Subcriteria }\end{array}$ & $\begin{array}{l}\text { Weight } \\
\text { (\%) }\end{array}$ & $\begin{array}{c}\text { Level III } \\
\text { Components }\end{array}$ & $\begin{array}{c}\text { Weight } \\
(\%)\end{array}$ \\
\hline \multirow{10}{*}{ Economic } & \multirow{10}{*}{15} & \multirow{3}{*}{ land prices } & \multirow{3}{*}{4} & high & 0.60 \\
\hline & & & & average & 1.15 \\
\hline & & & & low & 2.25 \\
\hline & & \multirow{3}{*}{$\begin{array}{l}\text { expenditures necessary for building } \\
\text { the infrastructure }\end{array}$} & \multirow{3}{*}{4} & high & 0.95 \\
\hline & & & & average & 1.30 \\
\hline & & & & low & 1.75 \\
\hline & & \multirow{3}{*}{ costs of servicing the plant } & \multirow{3}{*}{7} & high & 1.75 \\
\hline & & & & average & 2.20 \\
\hline & & & & low & 3.05 \\
\hline & & sum & 15 & & 15.00 \\
\hline \multirow{22}{*}{ Ecological } & \multirow{22}{*}{30} & \multirow{3}{*}{$\begin{array}{l}\text { emissions / location in relation to } \\
\text { the compass rose }\end{array}$} & \multirow{3}{*}{5} & favourable & 2.75 \\
\hline & & & & average & 1.60 \\
\hline & & & & adverse & 0.65 \\
\hline & & \multirow{3}{*}{ conditions of sewage collection } & \multirow{3}{*}{3} & favourable & 1.65 \\
\hline & & & & average & 0.95 \\
\hline & & & & adverse & 0.40 \\
\hline & & \multirow{3}{*}{ distance from landfill for hazardous waste } & \multirow{3}{*}{2} & favourable & 1.25 \\
\hline & & & & average & 0.60 \\
\hline & & & & adverse & 0.15 \\
\hline & & \multirow{3}{*}{$\begin{array}{l}\text { distance from residential areas / housing } \\
\text { development ratio }\end{array}$} & \multirow{3}{*}{7} & favourable & 3.95 \\
\hline & & & & average & 2.25 \\
\hline & & & & adverse & 0.80 \\
\hline & & \multirow{3}{*}{ distance from the ecologically valuable areas } & \multirow{3}{*}{7} & favourable & 4.05 \\
\hline & & & & average & 2.10 \\
\hline & & & & adverse & 0.85 \\
\hline & & \multirow{3}{*}{$\begin{array}{l}\text { possibility to use the obtained products } \\
\text { (energy, slags) in the nearest area of location }\end{array}$} & \multirow{3}{*}{4} & favourable & 2.65 \\
\hline & & & & average & 1.00 \\
\hline & & & & adverse/none & 0.35 \\
\hline & & \multirow{3}{*}{$\begin{array}{c}\text { the possibility of the use of renewable } \\
\text { energy sources }\end{array}$} & \multirow{3}{*}{2} & favourable & 1.05 \\
\hline & & & & average & 0.80 \\
\hline & & & & adverse/none & 0.15 \\
\hline & & sum & 30 & & 30.00 \\
\hline
\end{tabular}

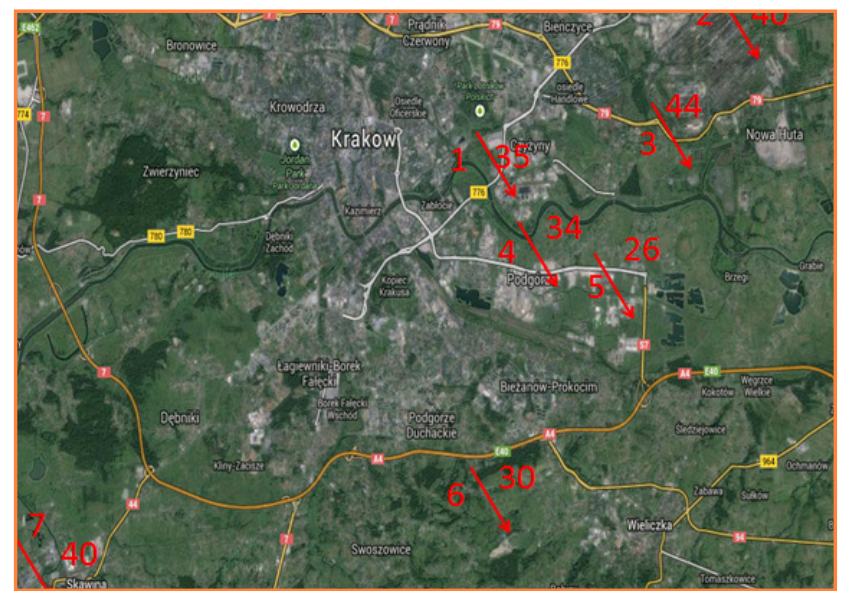

Figure 2 The results obtained for the tested objects calculations were used to compare the investigated objects (1-7) and to indicate the optimal location (Figure 2).

The calculation results showed that for the seven tested location points, values vary in the range from 26 to 44 (figure2). The optimal location is the object number 3.

\section{Conclusions}

The analytical hierarchical structure presented in this paper is useful in many processes of analyzes related to the determination of decision-making relevancy. The AHP method used in this study proved to be a good tool for decision-making, for indication of the weights of attributes associated with the choice of the MWIP location. Another advantage of this method is the possibility to combine quantitative and qualitative factors in the process of 
comparative analyzes. As a result of the conducted analysis, numerical notation of each factor describing a given object is obtained, which helps avoiding errors in the evaluation. Therefore, it must be stated unequivocally that the presented method can be successfully applied in the point estimation of the features determining the choice location of an object of MWIP type, as well as the objects of other functions.

\section{References}

GRECO, S. - MATARAZZO, B. - SŁOWIŃSKI, R. 2001. Rough Sets Theory for Multicriteria Decision Analysis. In European Journal of Operational Research, 2001, p. 129.

HAINING, R. 2003. Spatial analysis of regional geostatistics data. Cambridge : University Press, 2003.

SAATY, T. L. 1977. A scaling method for priorities in hierarchical structures. In Journal of Mathematical Psychology. Academic Press, Inc.

SAATY, T.L. 1980. The Analytic Hierarchy Process. USA McGrow - Hill.
PIASEK, Z. - SIEJKA, M. 2003.Teoria hierarchii analitycznej do wyceny gruntów w strefach przybrzeżnych zbiorników retencyjnych. The theory of the analytical hierarchy for valuation of land in coastal zones of retention reservoirs. Teorie, badania symulowane i eksperymentalne. Theories, simulated and experimental research. Monografia. Monograph PK. Kraków : Cracow University of Technology.

YOXAS, G. - SAMARA, T. - SARGOLOGOU, L. - STOURNARAS, G. 2011. Multiple criteria analysis for selecting suitablesites for construction of sanitary landfill based on hydrogeological data. Case study of Kea Island (Aegean Sea, Hellas). Advances in the Research of Aquatic Environment, vol. 2, pp. 97-104. DOI 10.1007/978-3-642-24076-8.

ZELENOVIĆ VASILJEVIĆ, T. - SRDJEVIĆ, Z. - BAJČETIĆ, R. VOJINOVIĆ MILORADOV, M. 2012. GIS and the Analytic Hierarchy Process for Regional Landfill Site Selection in Transitional Countries: A Case Study From Serbia. In Environmental Management 49. pp. 445-458. DOI 10.1007/s00267-011-9792-3. 